ZalącZnils

DOI $10.21697 / z k .2020 .7 .13$
Uznanie autorstwa-Użycie niekomercyjne-Bez utworów zależnych
Zatącznik Kulturoznawczy 7/2020

TEMAT NUMERU 2: BADANIE MUZYKI POPULARNEJ / POPULAR MUSIC STUDIES

\title{
ROZWÓJ POLSKIEJ ROCKOLOGII
}

JAKUB KASPERSKI

Instytut Muzykologii UAM

Institute of Musicology,

Adam Mickiewicz University in Poznań

kaspera@amu.edu.pl

ORCID: 0000-0003-1495-0421

Mimo iż tytułowy termin „rockologia” nie zadomowił się na dobre w języku polskim ${ }^{1}$, to wydaje się on intuicyjnie zrozumiały - należałoby go pojmować jako całokształt wiedzy i nauki o rocku². Wiedza ta może być gromadzona i przechowywana w pamięci oraz doświadczeniach muzyków i słuchaczy-odbiorców, co w naukach etnograficznych określane bywa jako wiedza antropologiczna ${ }^{3}$. Wiąże się ją zwykle z pamięcią komunikacyjną (wiedza przekazywana z pokolenia na pokolenie, głównie drogą ustną) lub pamięcią zbiorową (intersubiektywną) ${ }^{4}$, a w psychologii najczęściej z pamięcią autobiograficzną (pamięć epizodyczna życiowych zdarzeń oraz pamięć

1 Próbował go upowszechnić m.in. Andrzej Dorobek w serii artykułów poświęconych muzyce rockowej, publikowanych w specjalnym dziale płockiego pisma artystyczno-literackiego „Gościniec Sztuki”, zatytułowanym właśnie Rockologia. Paweł Tański mówi z kolei o rock music studies, zob. P. Tański, Dyskursy, performanse tekstowe i narracje transmedialne polskich piosenek rockowych, „Tematy i Konteksty" 2018, nr 8 (13), s. 522-540, zwłaszcza 524.

2 Należy zaznaczyć, że chodzi tu o szerokie kulturowe rozumienie rocka, obejmujące zarówno jego wielokodowość artystyczną (muzyka, tekst, image, performans, grafika), jak i kontekst społeczno-polityczno-ekonomiczny (np. subkultury młodzieżowe, bunt, przemysł muzyczny). Zob. W. Burszta, M. Rychlewski, Odpowiedź na pytanie: po co nam rock?, [w:] A po co nam rock? Między dusza a ciałem, red. eidem, Warszawa 2003, s. 6-7.

3 Zob. A. Malewska-Szałygin, Antropologia i polityka - zastosowanie czy uwikłanie, w: Antropologia stosowana, red. M. Ząbek, Warszawa 2013, s. 41-54 (zwłaszcza s. 43).

4 Zob. M. Saryusz-Wolska, Wprowadzenie, [w:] Pamięć zbiorowa i kulturowa. Wspótczesna perspektywa niemiecka, red. eadem, Kraków 2009, s. 34-35. 
semantyczna, dotycząca faktów i znaczeń) ${ }^{5}$. Wiedzę o rocku posiadają, wytwarzają i upowszechniają także przedstawiciele środków masowego przekazu (prasy, radia, telewizji, Internetu), najczęściej w takich dziennikarskich formach, jak artykuły prasowe, audycje radiowe czy telewizyjne, co można by określić mianem „rockologii dziennikarskiej”. Znaczna część dziennikarzy muzycznych wychodzi jednak poza te krótkie formy, pisząc również popularyzatorskie książki o rocku. Ten typ wiedzy wiąże się z pamięcią kulturową (utrwalaną za pomocą oficjalnych nośników pamięci) ${ }^{6}$ i ma on charakter głównie popularnonaukowy. Jest też wreszcie trzeci typ rockologii - rockologia akademicka, obejmująca profesjonalne badania naukowe oparte na metodologiach poszczególnych dyscyplin, które dążą do obiektywnej prawdy poprzez weryfikację danych i falsyfikację twierdzeń, unikając przy tym uwikłania w interesy rynków muzycznych.

Na pytanie, gdzie szukać początków polskiej rockologii, trudno odpowiedzieć jednoznacznie. Rockologia rozwijała się bowiem w kraju równolegle z muzyką rockową. Niewątpliwie ważny przełom stanowiły fachowe opracowania dziennikarskie i publikacje popularnonaukowe, które wykazywały ambicje, by rzeczowo analizować, porządkować i interpretować nowo pojawiające się zjawiska kulturalno-społeczne, jakimi były kolejne odmiany muzyki rockowej. Warto tu wspomnieć przede wszystkim o pionierskich artykułach w piśmie „Jazz”, ukazującym się po odwilży październikowej, w którym od 1963 roku pojawiała się regularnie specjalna dwustronicowa wkładka poświęcona muzyce rozrywkowej, zatytułowana Kącik Fanatyków Piosenki. Później, w 1969 roku, przemianowano ją na Rytm i Piosenka o sześciostronicowym formacie ${ }^{7}$. Od tego czasu tematyka rockowa stała się jedną z ważniejszych w czasopiśmie, a o muzyce tej pisali m.in. Wiesław

5 Zob. A. Walczak, B. Wiśniewska, Pamięć autobiograficzna, „Psychiatria i Psychologia Kliniczna" 2011, nr 11 (1), s. 51-54.

6 Zob. M. Saryusz-Wolska, op. cit.

7 Anna Idzikowska-Czubaj podaje w swojej pracy, że dodatek ów funkcjonował od 1962 roku, natomiast Artur Mariusz Trudzik w swoim studium o piśmie "Jazz" twierdzi, że pojawił się on dopiero od numeru 11 (87) z 1963 roku Zob. A. Idzikowska-Czubaj, Rock w PRL-u. O paradoksach wspótistnienia, Poznań 2011, s. 15-16; A.M. Trudzik, Na początku był Jazz. 60 lat prasy muzycznej (jazz, rock) $w$ Polsce, „Zeszyty Prasoznawcze” 2017, t. 60, nr 1 (229), s. 183-200. 
Weiss, Wiesław Królikowski, Kamil Sipowicz i inni. Pismo to było wówczas jednym z nielicznych źródeł wiedzy o muzyce rockowej w PRL-u. Częściowo tematyka rockowa pojawiała się też w piśmie muzycznym „Non Stop”, które zaczęło wychodzić od 1972 roku, oraz w „Jazz Forum”, a także - choć w znacznie mniejszym zakresie - w innych ogólnopolskich czasopismach polityczno-społeczno-kulturalnych ${ }^{8}$.

Na przełomie lat 50. i 60. ukazały się pierwsze popularyzatorskie publikacje autorstwa Lucjana Kydryńskiego poświęcone wykonawcom szeroko rozumianej muzyki popularnej oraz fenomenowi piosenki ${ }^{9}$. W latach 70 . wyszły natomiast pierwsze książki omawiające muzykę rockową, jak choćby Muzyka jazzowa i rozrywkowa. Przewodnik Iskier Romana Waschko z 1970 roku $^{10}$ albo Rock od Presleya do Santany Marka Garzteckiego z 1978 roku ${ }^{11}$. Warto odnotować, że pierwsza ze wspomnianych prac była dziełem pionierskim, jeśli o chodzi o polską leksykografię rockową - stworzyła de facto grunt pod kolejne tego typu opracowania.

Omawiając twórczość z tej dekady, należy również pochylić się nad działalnością Wacława Panka - wywodzącego się z Opola muzykologa, absolwenta UW, który uchodzi za najbardziej poczytnego autora w całej historii polskiej muzykografii: szacuje się, że do dziś sprzedano łącznie ponad dwa miliony egzemplarzy jego książek, których ma na swoim koncie przeszło pięćdziesiąt. W latach 70. Panek opublikował kilka pozycji, które dotyczyły muzyki rockowej, jak choćby Jazz, beat, rozrywka (Warszawa 1973) oraz Mity muzycznej rozrywki. Z notatnika obserwatora (Warszawa 1976), będące szkicami o społecznych i kulturowych uwarunkowaniach muzyki rozrywkowej. Ponadto: Niemen (kształty mitu) (Wrocław - Brzeg 1974) - pionierska próba zmierzenia się z biografią tego artysty, a także Piosenka polska (Warszawa 1978) - pierwsze na rodzimym rynku wydawniczym studium gatunku

${ }^{8}$ Zob. A. Idzikowska-Czubaj, op. cit..

9 Np. L. Kydryński, Wierze piosence, Kraków 1959; idem, Znajomi z płyt, Kraków 1960; idem, Znajomi z Estrady, Kraków 1966.

10 R. Waschko, Muzyka jazzowa i rozrywkowa. Przewodnik Iskier, Warszawa 1970.

${ }^{11}$ M. Garztecki, Rock od Presleya do Santany, Kraków 1978. 
piosenki w Polsce w perspektywie historyczno-muzykologicznej ${ }^{12}$. Prócz tego w 1979 roku Panek przygotował tłumaczenie słynnego leksykonu Joachima Ernsta Berendta Od raga do rocka. Wszystko o jazzie ${ }^{13}$. Z kolei w 1986 roku założył pierwsze pismo poświęcone profesjonalnemu show-businessowi: „Forum Rozrywki” ${ }^{14}$. W tym samym roku wydano też jego Mały słownik muzyki rozrywkowej ${ }^{15}$, który po wspomnianym Przewodniku Iskier był jedną z pierwszych w Polsce prób stworzenia słownika rzeczowego, a w zasadzie można by rzec - małej encyklopedii wiedzy o muzyce popularnej, w której to pracy hasła poświęcone rockowi stanowiły znaczącą część. Warto zauważyć, że późniejsze publikacje leksykograficzne Panka, takie jak Encyklopedia muzyki rozrywkowej ${ }^{16}$ z 2000 czy Nowy słowniczek muzyczny ${ }^{17}$ z 2014 roku, są rozwinięciami owego Małego słownika.

Pomimo erupcji rocka w Polsce i popularności festiwalu w Jarocinie lata 80 . nie przyniosły generalnie zbyt wielu prac rockologicznych, co zapewne związane było z permanentnym kryzysem ekonomiczno-politycznym tej dekady. Nie licząc wspomnianych już opracowań Panka, odnotować trzeba rozważania językoznawcze na temat tekstów rockowych, które podjęła w kilku artykułach pochodzących z tego okresu Halina Zgółkowa ${ }^{18}$. Niewątpliwie jednak największym przełomem w rozwoju rodzimej rocko-

12 W. Panek, Niemen (kształty mitu), Wrocław - Brzeg 1974; idem, Jazz, beat, rozrywka, Warszawa 1973; idem, Mity muzycznej rozrywki. $Z$ notatnika obserwatora, Warszawa 1976; idem, Piosenka polska, Warszawa 1978 (współautor: Lech Terpiłowski).

${ }_{13}$ Joachim Ernst Berendt, Od raga do rocka. Wszystko o jazzie, tłum. W. Panek, Kraków 1979.

${ }^{14}$ http://panek.arway.waw.pl/index.php/media oraz Wacław Panek - autor podręcznika do wiedzy o kulturze http://www.wydawnictwopolskie.pl/index.php/o-autorze-podrecznika-do-wok [data dostępu 20.01.2020].

15 W. Panek, Mały słownik muzyki rozrywkowej, Warszawa 1986.

16 Idem, Encyklopedia muzyki rozrywkowej, Warszawa 2000.

17 Idem, Nowy słowniczek muzyczny. Klasyka, folk, jazz, pop, rock, instrumenty, teoria, Wołomin 2014.

${ }_{18}$ Za przykład mogą posłużyć chociażby następujące publikacje Haliny Zgółkowej: „Miny na pokaz, czyny za grosz...”. O tekstach polskiego rocka, „Nurt” 1984, nr 1; Teksty rockowe: schematy myśli i języka, „Nurt” 1986, nr 5 (współautor K. Szymoniak). 
logii był początek lat 90., kiedy to zniknęła cenzura, otworzyły się granice odgradzające dotąd Polaków od świata Zachodu i jego kultury oraz pojawił się wolny rynek wydawniczy. $\mathrm{W}$ tym historycznym momencie apetyt na wiedzę o rocku (wiedzę dotąd mniej lub bardziej reglamentowaną przez władze komunistyczne) musiał być szybko i w pełni zaspokojony. To właśnie wówczas pojawiła się słynna seria popularyzatorska Lekka Muza pod redakcją Dariusza Michalskiego, która obejmowała kolejne tomy: 1. Cały ten jazz $z^{19} ; 2$, Rock przez caly rok; 3. Komu piosenkę?; 4. Z piosenka dookoła świata; 5: Za kulisami przeboju ${ }^{20}$. Rocka i jego wykonawców najszerzej omawiano - rzecz jasna - w tomie drugim; mimo iż w pozostałych ta tematyka również się pojawiała, to jednak w mniejszym zakresie.

Swoistym signum temporis było również powstanie w 1991 roku wydawnictwa muzycznego In Rock w Poznaniu, które - zgodnie ze swoją nazwą zaczęło się specjalizować niemal wyłącznie w publikowaniu książek o rocku. Do dziś wydało w sumie ponad 150 pozycji o tej tematyce. Są wśród nich przystępne biografie artystów i zespołów, autobiografie, bogato ilustrowane albumy, antologie tekstów i przekładów oraz śpiewniki. Jeśli chodzi o zakres czasowy i geograficzny, wydawnictwo sięga zarówno do klasycznych wykonawców rocka, jak i do najnowszych gwiazd tej muzyki, do artystów zagranicznych (głównie z kręgu anglosaskiego) oraz krajowych ${ }^{21}$.

Lata 90. przyniosły ze sobą również ważne opracowania encyklopedyczne poświęcone wyłącznie polskiej muzyce rockowej, jak choćby Encyklopedia polskiej muzyki rockowej. Rock'n'roll 1959-1973, napisana przez Jana

19 Pierwszy tom miał wielu autorów: Juliusz Jerzy Herlinger, Andrzej Jakubowicz, Maria Jurkowska, Lucjan Kydryński, Antoni Marianowicz, Dariusz Michalski, Aleksander Jerzy Rowiński, Andrzej Stankiewicz, Adam Warecki, Cały ten „jazz", Warszawa 1990.

20 D. Michalski, 2. Rock przez caly rok; 3. Komu piosenkę?; 4. Z piosenka dookoła świata; 5. Za kulisami przeboju, Warszawa 1990.

${ }^{21}$ https://inrock.pl/o-nas/ [dostęp 20.01.2020]. Nie miejsce tu na wymienianie wszystkich publikacji tego wydawnictwa, warto jednak wspomnieć, że w swojej ofercie ma ono również publikacje monograficzne o takich zespołach i artystach, jak choćby: Kate Bush, Tori Amos, Guns N’Roses, U2, Pink Floyd, The Rolling Stones, System of a Down, Thirty Seconds to Mars, The Police, Tool, Linkin Park, Metallica, Nirvana, Sabaton, a z polskich - T. Love, Dżem i wiele, wiele innych. 
Kaweckiego, Janusza Sadłowskiego, Marka Ćwikłę i Wojciecha Zająca w 1995 roku $^{22}$, oraz dwukrotnie wznawiana $(2001,2006)$ Encyklopedia polskiego rocka autorstwa Leszka Gnoińskiego i Jana Skaradzińskiego z 1996 roku $^{23}$. Ukazały się też encyklopedie poświęcone w większej mierze zagranicznej niż polskiej muzyce rockowej, jak np. dwutomowa Rock Encyklopedia Wiesława Weissa (cz. 1 - 1991 r., cz. 2 - 1994 r.) ${ }^{24}$, mająca być podstawą późniejszej, monumentalnej trzytomowej Wielkiej Rock Encyklopedii, albo Ilustrowany leksykon muzyki popularnej z 2002 autorstwa Ryszarda Glogera i Wojciecha Skrzydlewskiego ${ }^{25}$. Leksykografia o zagranicznych wykonawcach rozwinęła się również za sprawą poznańskiej Oficyny Wydawniczej Atena, która od 1994 roku zaczęła wydawać serię zatytułowaną Encyklopedia Muzyki Popularnej. Każdy kolejny tom poświęcony był bądź to innemu gatunkowi muzycznemu, bądź kolejnym dekadom rozwoju muzyki popularnej. Encyklopedie te były w głównej mierze tłumaczeniami brytyjskiej serii The Guinness Who's Who of..., z pewnymi korektami, rozszerzeniami i uzupełnieniami polskich redaktorów. I tak oto w latach 90. oraz w pierwszej dekadzie XXI wieku ukazały się oddzielne tomy dotyczące muzyki folk, hard rocka i heavy metalu, bluesa, bluesa w Polsce oraz jazzu, ponadto tom omawiający rap, dance i techno, a także tomy poświęcone latom 60., 70. i 80. ${ }^{26}$ Warto tu zaznaczyć, że prace te, razem z encyklopediami rockowymi z początków dekady, zawierały bogatą faktografię, dobrze zredagowane

${ }^{22}$ M. Ćwikła, J. Kawecki, J. Sadłowski, W. Zając, Encyklopedia polskiej muzyki rockowej. Rock'n'roll 1959-1973, Kraków 1995.

23 L. Gnoiński, J. Skaradziński, Encyklopedia Polskiego Rocka, Poznań 1996.

24 W. Weiss, Rock Encyklopedia, cz. 1-2, Warszawa 1991-1994.

25 R. Gloger, W. Skrzydlewski, Ilustrowany leksykon muzyki popularnej, Poznań 2002.

26 T. Gale, Encyklopedia Muzyki Popularnej. Lata sześćdziesiąte, Poznań 1995; W. Ossowski, K. Sawala, Encyklopedia Muzyki Popularnej. Folk, Poznań 1996; S. Pękała, B. Świątkowska, H. Wrona, Encyklopedia Muzyki Popularnej. Rap, dance \& techno, Poznań 1997; M. Jakubowski, M. Szalbierz, Encyklopedia Muzyki Popularnej. Blues w Polsce, Poznań 1997; R. Gloger, Encyklopedia Muzyki Popularnej. Heavy rock, Poznań 2000; C. Larkin, Encyklopedia muzyki popularnej. Lata osiemdziesiąte, Poznań 2004. D. Piątkowski, Encyklopedia Muzyki Popularnej. Jazz, Poznań 2005. 
biogramy poszczególnych artystów i zespołów, a czasem także informacje o wydawnictwach, natomiast dość słabo wypadały pod względem wiedzy rzeczowej. Z tomu Folk, pomimo dołączenia na końcu specjalnego krótkiego Słowniczka, nie dowiemy się np., czym różni się skiffle od folk rocka, folk celtycki od bretońskiego czy rockabilly od hillbilly itd. Innymi minusem tych prac jest ich anglocentryzm - w zasadzie brakuje lub mamy do czynienia z zupełną marginalizacją haseł i informacji o muzyce nieanglojęzycznej, $\mathrm{w}$ tym polskiej. Nieco lepiej sytuacja się przedstawia w tomie Rap, dance i techno, gdzie zamieszczono dość rzetelny, choć również niezbyt rozbudowany słowniczek. Natomiast wyjątkiem było wzbogacanie publikacji nie tylko o słowniczek, ale też o polskich wykonawców i repertuar w tomie Heavy rock pod redakcją Ryszarda Glogera.

Pisząc o polskiej leksykografii rockowej przełomu wieków, nie można zapomnieć o Słowniku terminów muzyki rozrywkowej Adama Wolańskiego z roku 2000. Praca ta, choć czasem krytykowana za błędy merytoryczne (por. np. hasło headbanger), zawiera w sobie ważny aspekt praktyczny, wyjaśnia niejednokrotnie po raz pierwszy w polskiej literaturze - kluczowe pojęcia w muzyce rozrywkowej, a ponadto odwołuje się do przykładów autentycznego użycia danego terminu w tekstach prasowych ${ }^{27}$. Ukoronowaniem tej swoistej „ery encyklopedystów” były z pewnością trzy monumentalne prace: Leksykon polskiej muzyki rozrywkowej. Pop, rock, jazz, folk z 2003 roku autorstwa Ryszarda Wolańskiego, z odrębnym, świetnie zredagowanym tomem poświęconym polskiej dyskografii ${ }^{28}$, ponadto wspomniana już (w zamyśle trzytomowa) Wielka Rock Encyklopedia Weissa oraz Encyklopedia muzyki popularnej. Blues Marka Jakubowskiego ${ }^{29}$, która na tle pozostałych encyklopedii oficyny Atena nie tylko wyróżniała się objętością i starannością redakcji, ale zawierała też, oprócz klasycznych biogramów, znakomicie opracowane hasła rzeczowe dotyczące stylów i gatunków muzycznych, ważnych dla bluesa lokalizacji geograficznych oraz wydawnictw muzycznych, a nawet instrumentów. Wyraźnym symptomem schyłku popularności i zapotrzebowania na tego typu literaturę była deklaracja Weissa o zaprzestaniu

27 A. Wolański, Słownik terminów muzyki rozrywkowe, Warszawa 2000.

28 R. Wolański, Leksykon polskiej muzyki rozrywkowej. Pop, rock, jazz, folk, Warszawa 2003 (t. 1: A-M; t. 2: N-Ż; t. 3: Dyskografia, aneksy A-Ż).

29 M. Jakubowski, Encyklopedia Muzyki Popularnej. Blues, Poznań 2008. 
prac i finalna decyzja o niewydawaniu ostatniego, trzeciego tomu swojej encyklopedii. Autor argumentował to - po pierwsze - drastyczną różnicą między wynikami sprzedaży tomu pierwszego i drugiego, wskazującą na ewidentny spadek zainteresowania czytelników encyklopediami rockowymi, po drugie - ogromem pracy, która zupełnie nie przekładała się na adekwatny zysk finansowy. Weiss zwracał ponadto uwagę na coraz większe znaczenie Internetu, który z jednej strony stanowi źródło najbardziej aktualnej wiedzy o ulubionych artystach, a z drugiej - jest miejscem rozwoju piractwa (którego sam zresztą padł ofiarą). Wszystkie wspomniane tu czynniki działają na niekorzyść obszernych publikacji książkowych na temat muzyki rockowej ${ }^{30}$.

Mówiąc o latach 90., należy podkreślić, że w tej dekadzie rozwinęła się de facto polska rockologia akademicka, przynosząc ze sobą kluczowe dla kolejnych pokoleń prace, jak choćby To tylko rock'n roll! warszawskiego socjologa kultury młodzieżowej Jerzego Wertensteina-Żuławskiego ${ }^{31}$, będąca pokłosiem jego doktoratu z 1979 roku, czy Spontaniczna kultura młodzieżowa: wybrane zjawiska pod redakcją Wertensteina-Żuławskiego oraz Mirosława Pęczaka32. W 1993 roku ukazała się z kolei rozprawa habilitacyjna Wertensteina-Żuławskiego Między nadzieja a rozpacza: [rock, młodzież, społeczeństwo $]^{33}$, a także fundamentalna praca z zakresu kulturoznawstwa, uważana za pierwszą w Polsce całościową próbę interpretacji rocka jako fenomenu artystycznego i kulturowego, a mianowicie Estetyka rocka Wojciecha Siwaka ${ }^{34}$. Na przełomie wieków ukazało się też kilka prac poświęconych subkulturom młodzieżowym i kontrkulturze, np. w 1999 r.

3010 września 2016 roku Wiesław Weiss opublikował na swoim profilu facebookowym informację o zaniechaniu prac nad trzecim tomem. Zob. https://www. facebook.com/serwisprogrockorgpl/posts/1244652955556617/ [dostęp 20.01.2020].

${ }^{31}$ J. Wertenstein-Żuławski, To tylko rock'n roll!, posłowie A. Jawłowska, Warszawa 1990.

32 Spontaniczna kultura młodzieżowa: wybrane zjawiska, red. M. Pęczak, J. Wertenstein-Żuławski, Wrocław 1991.

${ }^{33}$ J. Wertenstein-Żuławski, Między nadzieja a rozpaczą: [rock, młodzież, społeczeństwo], Warszawa 1993. Zob. J. Kuroń, Umarł Jerzy WertensteinŻuławski, „Gazeta Wyborcza”, 30.10.1996, http://www.archiwum.wyborcza.pl/ Archiwum/1,0,229508,19961030RP- [dostęp 20.01.2020].

34 W. Siwak, Estetyka rocka, Warszawa 1993. 
wyszły Młodzież a subkultury Marka Jędrzejewskiego ${ }^{35}$ oraz Od subkultury do kultury alternatywnej: wprowadzenie do subkultur młodzieżowych Mariana Filipiaka ${ }^{36}$, w 2003 roku Od kontrkultury do popkultury Mariana Golki ${ }^{37}$ oraz Subkultury młodzieżowe. Aspekty psychospołeczne Przemysława Piotrowskiego ${ }^{38}$, a w 2005 zbiorowa praca pod redakcją Wojciech J. Burszty, Mariusza Czubaja i Marcina Rychlewskiego Kontrkultura: co nam z tamtych lat. ${ }^{39}$.

Swoista erupcja rockologii akademickiej nastąpiła w Polsce z nadejściem XXI wieku. Oprócz wspomnianych wcześniej publikacji pojawiły się m.in. niezwykle ważne i podparte materiałami źródłowymi prace historyczne o muzyce w PRL-u, jak choćby Rock a przemiany kulturowe końca XX wieku Beaty Hoffmann $(2001)^{40}$, Scena rockowa $w$ PRL. Historia, organizacja, znaczenie Przemysława Zielińskiego (2005) ${ }^{41}$, IPN-owski album Jarocin w obiektywie bezpieki autorstwa Krzysztofa Lesiakowskiego, Pawła Perzyny, Tomasza Toborka (2004) ${ }^{42}$, wnikliwa książka Rock w PRL-u. O paradoksach wspótistnienia Anny Idzikowskiej-Czubaj (2011) ${ }^{43}$ czy niedawno wydana Partia z piosenka, piosenka z partia. PZPR wobec muzyki rozrywkowej Karoliny Bittner $(2017)^{44}$. Nad rolą muzyki rockowej oraz szeroko rozumianej kultury popularnej w edukacji i wychowaniu dzieci i młodzieży zaczęli się również zastanawiać polscy pedagodzy. Godną polecenia jest

35 M. Jędrzejewski, Młodzież a subkultury, Warszawa 1999.

${ }_{36}$ M. Filipiak, Od subkultury do kultury alternatywnej: wprowadzenie do subkultur młodzieżowych, Lublin 1999.

37 M. Golka, Od kontrkultury do popkultury, Poznań 2002.

38 P. Piotrowski, Subkultury młodzieżowe. Aspekty psychospołeczne, Warszawa 2003.

39 Kontrkultura: co nam $z$ tamtych lat?, red. W.J. Burszta, M. Czubaj, M. Rychlewski, Warszawa 2005.

40 B. Hoffmann, Rock a przemiany kulturowe końca XX wieku, Warszawa 2001.

${ }_{41}$ P. Zieliński, Scena rockowa $w$ PRL. Historia, organizacja, znaczenie, Warszawa 2005.

${ }^{42}$ K. Lesiakowski, P. Perzyna, T. Toborek, Jarocin w obiektywie bezpieki, Warszawa 2004.

43 A. Idzikowska-Czubaj, op. cit.

44 K. Bittner, Partia z piosenka, piosenka z partia. PZPR wobec muzyki rozrywkowej, Warszawa 2017. 
zwłaszcza praca Witolda Jakubowskiego Edukacja w świecie kultury popularnej, z interesującym rozdziałem poświęconym pożytkom płynącym $\mathrm{z}$ wykorzystywania rocka w edukacji młodzieży ${ }^{45}$. Warto też zwrócić uwagę na wybrane prace i artykuły takich pedagogów, jak prof. Zbyszko Melosik czy prof. Wojciech Skrzydlewski ${ }^{46}$. Pojawiły się też wreszcie analizy szeroko rozumianego tekstu rockowego, jak choćby przełomowa dla kręgu akademickiego praca zbiorowa A po co nam rock? Między dusza a ciałem pod redakcją Wojciecha Burszty i Marcina Rychlewskiego czy publikacje Andrzeja Dorobka Rock - problemy, sylwetki, konteksty (szkice z estetyki i socjologii rocka) z 2001 roku ${ }^{47}$, Marcina Rychlewskiego Rewolucja rocka. Semiotyczne wymiary elektrycznej ekstazy (2011) ${ }^{48}$ czy, częściowo poświęcona tekstom rockowym, Apologia piosenki. Studia z historii gatunku Joanny Maleszyńskiej (2013) ${ }^{49}$. Ponadto w mijającej dekadzie ukazały się następujące prace, wpisujące się generalnie w studia literaturoznawcze, kulturoznawcze, medioznawcze oraz antropologiczne: Izoldy Kiec W szarej sukience? Autorki i wokalistki w poszukiwaniu tożsamości (2013); trzy książki Marka Jezińskiego - Muzyka popularna jako wehikuł ideologiczny (2011), Mitologie muzyki popularnej (2014), Muzyka popularna i jej odbiorcy w poszukiwaniu autorytetu (2017); Piosenka w poezji pokolenia ery transformacji 1984-2009 Piotra Łuszczykiewicza (2009); Nasłuchiwanie hałasu. Audioantropologia między ekspresją a doświadczeniem Dariusza Brzostka (2014); Dekada buntu. Punk $w$ Polsce i krajach sąsiednich w latach 1977-1989 Remigiusza Kasprzyckiego (2013); Okładki płyt. Rzecz o wizualnym uniwersum albumów muzycznych Mateusza Torzeckiego (2015); Nowe sytuacje polskiego rocka: teksty, głosy, interpretacje Pawła Tańskiego (2016); Szarpidruty i poeci. Piosenka wobec przemian społecznych i kulturowych ostatnich dekad Krzysztofa Gajdy (2017) czy Polska prasa muzyczna $w$ dobie transformacji ustrojowej. „Tylko

45 W. Jakubowski, Edukacja w świecie kultury popularnej, Kraków 2011.

${ }^{46}$ Np. R. Gloger, W. Skrzydlewski, op. cit.; Z. Melosik, Kultura popularna i tożsamość młodzieży. W niewoli władzy i wolności, Kraków 2013.

47 A. Dorobek, Rock-problemy, sylwetki, konteksty (szkice z estetyki i socjologii rocka), Bydgoszcz 2001.

48 M. Rychlewski, Rewolucja rocka. Semiotyczne wymiary elektrycznej ekstazy, Gdańsk 2011.

49 J. Maleszyńska, Apologia piosenki. Studia z historii gatunku, Poznań 2013. 
Rock"1991-2002 Artura Trudzika (2017). W dużej mierze publikacje te były dysertacjami doktorskimi, habilitacyjnymi bądź pracami profesorskimi, umożliwiającymi, z jednej strony, awans naukowy ich autorom, $\mathrm{z}$ drugiej zaś świadczącymi o tym, jak głęboko badania nad muzyką rockową i piosenką zakorzeniły się w polskiej humanistyce.

Przyglądając się poszczególnym dyscyplinom i zainteresowaniom ich przedstawicieli muzyką rockową, nie sposób nie wspomnieć o muzykologii, która jako nauka o muzyce powinna być - zdawałoby się - żywotnie zainteresowana omawianym tu zagadnieniem. Głównie jednak ze względów historycznych, ideologicznych i metodologicznych muzyka popularna przez długi okres nie była włączana w zakres badań polskich muzykologów ${ }^{50}$. Słuszne więc były utyskiwania Marcina Rychlewskiego niemal dekadę temu we wstępie do jego Rewolucji rocka, że „muzykolodzy pozostają najwyraźniej badawczo bezradni wobec rocka, skoro jedynym, jak dotąd, polskim artykułem pisanym z tej perspektywy jest interesujący szkic W stronę muzykologii rocka Grzegorza Piotrowskiego" "'. Wspomnianego tu Piotrowskiego faktycznie należałoby uznać za pioniera badań nad rockiem i szeroko rozumianą muzyką popularną w polskiej muzykologii XXI w. Oprócz tekstu wzmiankowanego przez Rychlewskiego spośród utworów naukowych Piotrowskiego warto przywołać chociażby jego pracę magisterską poświęconą twórczości Ałły Pugaczowej - najważniejszej rockowej wokalistki rosyjskiej ${ }^{52}$. Natomiast niewątpliwie przełomowym dziełem tego autora jest książka Muzyka popularna. Nastuchy i namysty, zwłaszcza zaś trzeci rozdział (Muzyka popularna III: kod muzyczny), dotyczący m.in. muzycznego idiomu rocka ${ }^{53}$. Na fachowe zajęcie się wielokodowością rocka pozwoliły temu badaczowi szerokie kompetencje, bowiem oprócz studiów muzykologicznych ukończył też polonistykę, od wielu lat pracuje w Katedrze

50 Zob. J. Kasperski, Tożsamość muzykologii w pespektywie badań nad muzyka popularna, [w:] Kultura popularna w społeczeństwie współczesnym. Teoria i rzeczywistość, red. J. Drozdowicz, M. Bernasiewicz, Kraków 2010.

${ }_{51}$ M. Rychlewski, op. cit., s. 11.

${ }^{52}$ Na podstawie tej pracy opublikowano później książkę. Zob. G. Piotrowski, Ałła Pugaczowa - fenomen piosenkarstwa rosyjskiego, Toruń 2003.

53 Idem, Muzyka popularna. Nasłuchy i namysty, Warszawa 2016, zwłaszcza s. $67-104$. 
Kulturoznawstwa Uniwersytetu Gdańskiego, a dodatkowo jest też czynnie działającym muzykiem-wokalistą.

Jeśli chodzi jednak o polską muzykologię, to - nie licząc Piotrowskiego w ostatnich latach dokonał się istotny przełom na gruncie tej dyscypliny, gdyż nie tylko muzyka popularna zaczęła się pojawiać w mniejszym lub większym zakresie w programach studiów muzykologicznych, ale też kilku muzykologów młodszego pokolenia obrało muzykę rockową jako przedmiot specjalizacji. Piszący te słowa obronił w 2012 roku dysertację doktorską pt. Muzyka popularna jako przedmiot badań muzykologii, której rozdziały analityczne dotyczyły muzyki rockowej ${ }^{54}$. Praca ta nie tylko ukazuje problematykę definiowania tytułowego zjawiska, ale również nakreśla historię i najważniejsze nurty badań muzyki popularnej na świecie oraz wskazuje ideologiczne i metodologiczne przyczyny wyłączania tego repertuaru z zakresu zainteresowań muzykologii. Z kolei w 2015 roku Mariusz Gradowski napisał i obronił na Uniwersytecie Warszawskim swój doktorat pt. Style i gatunki polskiej muzyki młodzieżowej w latach 1957-1973, który w wersji książkowej ukazał się w 2018 roku nakładem Oficyny Wydawniczej ASPRA ${ }^{55}$. Oprócz tego należy odnotować coraz większy odsetek prac licencjackich i magisterskich poświęconych muzyce rockowej w ostatnich latach wśród młodych adeptów muzykologii. Ciągle jednak niewielu jest doktorantów, którzy chcieliby rozwijać swoją karierę naukową w tym kierunku. Otwarcie się polskiej muzykologii na muzykę rockową (choć znacząco zapóźnione zarówno w stosunku do krajów Zachodu, jak i innych dyscyplin humanistycznych w Polsce) należy jednak uznać za fakt dokonany. Warto też przy okazji nadmienić, że istotnym przełomem w sensie instytucjonalnym było powołanie do życia w 2016 roku Pracowni Badań nad Muzyką Tradycyjną i Popularną w ramach restrukturyzowanego Instytutu Muzykologii UAM, zapewne pierwszej historycznie jednostki naukowej w Polsce mającej w nazwie jeszcze co prawda nie sam rock, ale już - muzykę popularną.

54 J. Kasperski, Muzyka popularna jako przedmiot badań muzykologii, praca doktorska napisana pod opieką prof. dra hab. Ryszarda Daniela Golianka, UAM, Poznań 2012.

55 M. Gradowski, Big beat. Style i gatunki polskiej muzyki młodzieżowej w latach 1957-1973, Warszawa 2018. 
W ostatnich dwóch dekadach pojawiły się też pierwsze konferencje naukowe poświęcone nie tylko samej muzyce rockowej, ale również piosence, muzyce lub kulturze popularnej, zatem tematom, w które rock się wpisywał. Sympozja te miały jednak zwykle charakter pojedynczych wydarzeń. Za przykład mogą tu posłużyć chociażby: „Rock i polityka” w Gdańsku w czerwcu 2000 roku; „W teatrze piosenki” w Poznaniu w listopadzie 2004 roku; „Sztuka i polityka - muzyka popularna” w Toruniu w październiku 2009 roku; „Depeche Mode - muzyka, zjawisko, recepcja” w Toruniu w lutym 2011 roku albo konferencja zatytułowana „Kto, co i dlaczego nami rządzi, czyli: Literatura i kultura popularna a władza”, zorganizowana we Wrocławiu w listopadzie 2013 roku. W rezultacie tych zjazdów powstawały tomy pokonferencyjne pokazujące niezwykle szerokie spektrum ujęć i problematyk związanych z zakresem badawczym, jakim jest rock i zagadnienia mu pokrewne, m.in.: W teatrze piosenki pod redakcją Izoldy Kiec i Michała Tkaczyka ${ }^{56}$, Między przymusem a akceptacja. Meandry władzy w literaturze $i$ kulturze popularnej pod red. Anny Gemry i Konrada Dominasa ${ }^{57}$ oraz „Chodzac w ich butach”. Depeche Mode - muzyka, zjawisko, recepcja pod redakcją Marcina Jurzysty, Michała Pranke i Pawła Tańskiego ${ }^{58}$.

Przełom pierwszej i drugiej dekady XXI w. przyniósł jednak polskiej nauce nowy, niespotykany wcześniej trend. Chodzi mianowicie o cykliczne, interdyscyplinarne konferencje naukowe poświęcone muzyce rockowej, które nie tylko pozwoliły rozwinąć, ale też w dużym stopniu skonsolidować polską rockologię, głównie za sprawą nawiązywania bezpośrednich kontaktów między akademikami, a także podejmowania dialogu między poszczególnymi badaczami oraz reprezentowanymi przez nich dyscyplinami. Najstarszym i jednym z najważniejszych tego typu wydarzeń są coroczne kameralne spotkania „Unisono na pomieszane języki” (po trzeciej edycji: „Unisono w wielogłosie”). Odbywają się one od 2009 roku w Tułowicach pod Opolem, a organizowane są przez dra Radosława Marcinkiewicza. Początkowo skoncentrowane były wokół postaci Czesława Niemena i jego

56 W teatrze piosenki, red. I. Kiec, M. Tkaczyk, Poznań 2005.

${ }^{57}$ Między przymusem a akceptacja. Meandry władzy w literaturze i kulturze popularnej, red. A. Gemra, K. Dominas, Wrocław 2014.

58 "Chodzac w ich butach”. Depeche Mode - muzyka, zjawisko, recepcja, red. M. Jurzysta, M. Pranke, P. Tański, Toruń 2017. 
spuścizny twórczej, jednak w kolejnych latach to szeroko rozumiana muzyka rockowa stała się centralnym tematem zjazdów. Pokłosiem tych spotkań jest seria tomów pokonferencyjnych zatytułowanych „Unisono w wielogłosie”, których na chwilę obecną ukazało się sześć. Innym przykładem są trzy konferencje z serii „Kultura rocka”, odbywające się od 2015 roku na Uniwersytecie Mikołaja Kopernika w Toruniu z inicjatywy prof. Pawła Tańskiego, Jakuba Osińskiego i Michała Pranke. Niejako kontynuacją tego cyklu były podobne wydarzenia naukowe organizowane na tej uczelni w kolejnych latach: „Polski rock lat 80. Nurty, gwiazdy, media, fani, kontynuacje” (grudzień 2016) czy „Muzyczny rok 1969 i jego kulturowe implikacje” (wrzesień 2019). Kolejnym ważnym cyklicznym wydarzeniem są konferencje „MUTE (Muzyka, Uniwersytet, Technologia, Emocje)”, organizowane pod patronatem prof. Andrzeja Juszczyka przez grupę młodych badaczy z Wydziału Polonistyki na Uniwersytecie Jagiellońskim z inicjatywy kulturoznawcy Konrada Sierzputowskiego, z założenia mające się wpisywać w szeroko rozumianą anglosaską tradycję popular music studies. Zjazdy te wyróżniała m.in. możliwość spotkań i rozmów z przedstawicielami polskiej sceny muzycznej oraz rodzimego przemysłu muzycznego (np. Czesław Mozil, Paweł Sołtys, Ten Typ Mes itd.). Ciekawą inicjatywą była też próba powołania do życia pierwszego w Polsce stowarzyszenia badaczy muzyki popularnej o eponimicznej nazwie MUTE, nadal jednak niezrealizowana. Oprócz tego na Uniwersytecie Pedagogicznym im. KEN w Krakowie odbywa się jeszcze jedno cykliczne wydarzenie naukowe o bardziej sprofilowanej tematyce rockowej, świadczące o tendencjach do uszczegóławiania i rozdrabniania dyskursu rockologicznego w kraju. Mowa tu konferencjach metal studies, które za sprawą zaangażowania ich głównego pomysłodawcy i organizatora dra Jakuba Koska odbyły się już trzykrotnie, a kolejne są w planach. Na mapie polskiego życia naukowego i koncertowego ważną rolę zaczęły też odgrywać poznańskie „Frazy. Festiwal słowa w piosence”, organizowane regularnie od 2015 roku z inicjatywy prof. Krzysztofa Gajdy w ramach kooperacji między Biblioteką Raczyńskich a Uniwersytetem im. A. Mickiewicza w Poznaniu. Koncertom, konkursom muzycznym i spotkaniom autorskim towarzyszy konferencja tematyczna skoncentrowana wokół relacji słowno-muzycznych w piosence. Znaczna cześć referatów wygłaszanych na poznańskich „Frazach” dotyczy tematyki rockowej. Efekty dotychczasowych konferencji można odnaleźć w tomie Etyka i estetyka 
stowa w piosence (2019) ${ }^{59}$, a prace nad publikacją tekstów z ostatnich festiwali-konferencji nadal trwają.

Jednym z najwyrazistszych przejawów dywersyfikacji dyskursu i wyłaniania się nowych, specjalistycznych gałęzi polskiej rockologii jest niewątpliwie rozwój niemenologii, czyli studiów nad osobą i twórczością Czesława Niemena - czołowego przedstawiciela polskiej muzyki popularnej. Choć jeszcze za życia artysty pojawiały się poświęcone mu publikacje książkowe, to właściwa niemenologia rozwinęła się dopiero po śmierci Niemena w styczniu 2004 roku. Do rozwoju tej gałęzi rockologii przyczyniły się: wspomniane już wcześniej tułowickie „Unisona” i związane z nimi publikacje pokonferencyjne, niezależne ukazanie się na rynku kilku rzetelnych biografii muzyka $^{60}$, a także zloty fanowskie i imprezy upamiętniające artystę, z których najważniejszym niewątpliwie jest Festiwal Młodych Talentów „Niemen Non Stop" organizowany od 2006 roku w Słupsku. W ramach festiwalu redaktor Roman Radoszewski zainicjował w 2009 roku panele dyskusyjne „Nota Anamnesis" dotyczące twórczości Niemena, które w 2013 roku przekształciły się w regularne konferencje naukowe pod auspicjami lubelskiego Ośrodka Badań nad Twórczością Cypriana Norwida KUL. Pokłosiem tych spotkań są trzy pokonferencyjne tomy studiów nad dorobkiem artystycznym tego wybitnego twórcy zatytułowane Czesław Niemen i jego plytowe dzieła ${ }^{61}$.

Mówiąc o rozwoju polskiej rockologii akademickiej, nie można rzecz jasna nie wspomnieć o pismach naukowych, umożliwiających badaczom rocka publikację tekstów i stanowiących platformę dialogu i wymiany wiedzy. Należy tu zwłaszcza wspomnieć o recenzowanym roczniku „Literatura i Kultura Popularna", finansowanym i wydawanym przez Wydział Filologiczny Uniwersytetu Wrocławskiego już od 1991 roku $^{62}$ Kolejnym periodykiem

${ }^{59}$ Etyka i estetyka słowa w piosence, red. K. Gajda, M. Chrząstowska, Poznań 2019.

60 R. Radoszewski, Czesław Niemen. Kiedy się dziwić przestanę... Monografia artystyczna, Warszawa 2004; T. Skliński, Niemen. Dyskografia, fakty, twórczość, Warszawa 2006; D. Michalski, Czesław Niemen. Czy go jeszcze pamiętasz?, Warszawa 2009.

${ }^{61}$ Czesław Niemen i jego płytowe dzieła, red. E. Chlebowska, P. Chlebowski, współudział Ł. Niewczas, Lublin, cz. 1: 2014, cz. 3: 2017, cz. 3: 2020.

${ }^{62}$ http://wuwr.pl/lkp [dostęp 20.01.2020]. 
jest „Kultura Popularna” - kwartalnik naukowy wydawany od 2002 roku Warszawie. Jego założyciel to medioznawca prof. Wiesław Godzic, który od momentu założenia pisma, aż do 2019 roku pozostawał jego redaktorem naczelnym. Zgodnie z deklaracją wydawców „celem naukowym czasopisma jest analiza kultury codzienności, nowych technologii, sztuki współczesnej, a także wszelkich obszarów związanych z zainteresowaniami społeczeństwa masowego. Aspiracją kwartalnika jest uchwycenie dynamicznych zmian zachodzących w kulturze popularnej, bez pominięcia jej kontrowersyjnych, czy znajdujących się w sferze społecznego tabu, aspektów" ${ }^{63}$. Z nowych pism trzeba też wspomnieć o „Studiach z Kultury Popularnej” - roczniku naukowym poświęconym „refleksji nad historią, teorią i metodologią badań kultury popularnej” oraz „diagnozie jej współczesnego kształtu”, ukazującym się w Poznaniu od 2017 roku za sprawą działającej od 2014 roku Fundacji Instytut Kultury Popularnej ${ }^{64}$. Nie można tu także zapomnieć o „Przeglądzie Kulturoznawczym” czy „Kulturze Współczesnej”, które poświęciły całe tomy audioantropologii, a także o - wydawanym przez Muzeum Polskiej Piosenki w Opolu ${ }^{65}$ - roczniku kulturalnym „Piosenka”66.

Na pograniczu muzycznej publicystyki i popularyzatorskiej nauki działają też dwa ważne dla rockologii pisma: „Glissando” - magazyn o muzyce współczesnej, wychodzący w Warszawie od 2004 roku (zwłaszcza poświęcony

${ }^{63} \mathrm{https}$ //www.swps.pl/nauka-i-badania/dzialalnosc-wydawnicza/czasopisma/ kultura-popularna [dostęp 20.01.2020].

${ }^{64} \mathrm{http}$ ://fundacja-ikp.pl/wydawnictwo/page/2/ [dostęp 20.01.2020].

${ }^{65}$ Jest to muzeum powołane do życia 29 listopada 2007 roku uchwałą Rady Miasta Opola, a otwarte dla szerokiej publiczności w sierpniu 2016 roku. Zgodnie ze statutem „do zakresu działania Muzeum należy prowadzenie działalności dokumentacyjnej, wystawienniczej, edukacyjnej, kulturalno-oświatowej i popularyzacyjnej w zakresie sztuki współczesnej, a zwłaszcza polskiej piosenki”. Muzeum gromadzi zbiory z zakresu archiwaliów, fotografii, fonografii, mody, numizmatyki, sztuki i techniki związane z polską piosenką oraz festiwalem opolskim. Zob. Uchwała nr XLII/825/17 Rady Miasta Opola z dnia 25 maja 2017 r. w sprawie nadania statutu Muzeum Polskiej Piosenki w Opolu, Dz.U. Województwa Opolskiego, 5.06.2017 r., https://muzeumpiosenki.pl/pliki/Statut_Muzeum_Polskiej_Piosenki. pdf [dostęp 22.03.2020].

${ }^{66}$ https://muzeumpiosenki.pl/piosenka-rocznik-kulturalny.html [dostęp 22.03.2020]. 
rockowi nr 13 i 14 z grudnia 2007 roku), a także „Gazeta Magnetofonowa” kwartalnik omawiający polską muzykę popularną, wydawany od grudnia 2015 roku przez wydawnictwo Trzecie Ucho ${ }^{67}$. Nie do przecenienia dla rockologii są również liczne popularne czasopisma poświęcone tej muzyce, które z mniejszymi lub większymi przerwami - ukazywały się albo nadal ukazują się w Polsce, jak choćby „Magazyn Muzyczny” (1983-1991) i jego następcy: „Tylko Rock” (1991-2003), a potem „Teraz Rock” (po 2003), „Machina” (1995-2002, 2006-2012), „Muza” (2003), „Brum” (1993-1999), „Aktivist” (od 2000), „Pulp” (2007-2010) „Gitara i Bass” (1992-2005) „Magazyn Gitarzysta” (od 2006) i wiele innych.

Ważnym fenomenem rodzimego rynku wydawniczego początku XXI w. stały się też coraz liczniej ukazujące się biografie czy autobiografie przedstawicieli polskiej sceny rockowej, często ujęte w formie wywiadu rzeki lub wspomnień. Bazują one na zasobach pamięci autobiograficznej i komunikacyjnej, o których mowa była na początku artykułu. Ciekawymi reprezentantami tego gatunku są chociażby: Gościu: Auto-Bio-Grabaż Krzysztofa "Grabaża” Grabowskiego (2010) ${ }^{68}$, Idę tam gdzie idę. Autobiografia Kazika Staszewskiego $(2015)^{69}$, Wagiel. Jeszcze wszystko będzie możliwe Wojciecha Waglewskiego $(2017)^{70}$ czy A ja żem jej powiedziała... Katarzyny Nosowskiej $(2018)^{71}$.

Podsumowując przedstawione tu rozważania, można stwierdzić, że, po pierwsze, polska rockologia ma się całkiem dobrze, jest już znacząco rozwinięta i umocowana instytucjonalnie, a osoby zainteresowane tematyką muzyki i kultury rocka - zarówno zaangażowani fani, kolekcjonerzy, przedstawiciele branży muzycznej, jak i profesjonalni badacze akademiccy znajdą obszerne pokłady wiedzy zgromadzonej w setkach artykułów

${ }^{67}$ Jacek Szubrycht - redaktor naczelny „Gazety Magnetofonowej” - zamieścił 2 marca 2020 roku na swoim profilu facebookowym informację o zawieszeniu wydawania pisma. https://www.facebook.com/szubrycht/posts/10215660159248731 [dostęp 22.03.2020].

${ }^{68}$ K. Gajda, K. Grabowski, Gościu: Auto-Bio-Grabaż, Poznań 2010.

69 R. Księżyk, K. Staszewski, Idę tam gdzie idę. Autobiografia, Warszawa 2015.

70 W. Bonowicz, W. Waglewski, Wagiel. Jeszcze wszystko będzie możliwe, Kraków 2017.

${ }^{71}$ K. Nosowska, A ja żem jej powiedziała..., Warszawa 2018. 
licznych czasopism tematycznych i dziesiątkach książek, które opublikowano w ostatnich dekadach. Jest to ponadto rockologia różnych wymiarów - fanowska, popularnonaukowa i stricte naukowa. Po drugie, należy zauważyć pewną wyraźną tendencję w ostatnich dekadach: gromadzeniem wiedzy o rocku zajmują się już nie tylko fani czy dziennikarze muzyczni, ale również coraz liczniejsi pracownicy naukowi, będący przedstawicielami różnorodnych dyscyplin humanistycznych. Co więcej, robią to coraz lepiej, intensywniej (wzrost liczby publikacji i konferencji o muzyce rockowej) i w coraz bardziej usystematyzowany sposób (pojawienie się sympozjów i publikacji monograficznych, specjalistycznych i cyklicznych). Po trzecie, na polskiej mapie można wskazać kilka wiodących ośrodków rockologii akademickiej w Polsce - są to niewątpliwie: Kraków (UJ, UP), Poznań (UAM, FIKP), Toruń (UMK) i Opole (UO, MPP), a nieznacznie tylko ustępują im Warszawa czy Wrocław.

Czy jednak nakreślony tu rozwój polskiej rockologii będzie podtrzymany w najbliższych latach? Z pewnością będzie stabilny, choć w kolejnych dekadach ten impet może zostać nieco wyhamowany. Przyglądając się bowiem muzyce popularnej w perspektywie historycznej, należy mieć świadomość, że rock jest tylko jednym z jej nurtów. Zapewne najważniejszym, jeśli chodzi o znaczenie społeczne i artystyczne, ale ciągle tylko jednym z wielu. Lata swojej świetności ma już za sobą, a jego śmierć pod koniec XX wieku w dramatycznym tonie obwieszczało wielu dziennikarzy muzycznych. Znamienna jest chociażby wypowiedź Grzegorza Brzozowicza w artykule Początek $i$ koniec rocka, będącym notabene kodą jednej z pierwszych polskich książek akademickich o tej muzyce - A po co nam rock: „Rock jest dziś martwą formą wypowiedzi. Doszedł do swojego twórczego kresu, tak jak jazz i kino na początku lat $80 . "{ }^{72}$. Nie wnikając w to, na ile teza ta jest prawdziwa, a na ile prowokatorska, trzeba podkreślić inną kwestię, mianowicie: że rock i związana z nim rockologia są zjawiskami pokoleniowymi. Muzykę tę wprowadzała na scenę młodzież lat 50. i 60., a odnawiały jej oblicze następne generacje. Rock na uniwersytety w prowadzali natomiast jego zagorzali fani, do czego zresztą większość z nich otwarcie się przyznaje ${ }^{73}$. Jednak muzyka ta nie jest już muzyką współczesnej młodzieży. Zaświadczają o tym nie tylko

72 G. Brzozowicz, Poczatek $i$ koniec rocka, [w:] A po co nam rock?, op. cit., s. 256.

73 Zob. W. Burszta, M. Rychlewski, op. cit., s. 4-7. 
siwiejący weterani rocka, których nie zastępują nowi, młodzi „wyjadacze”, ale również wyniki sprzedażowe wydawnictw i listy przebojów, zdominowane przez nurty muzyczne inne niż rock. Przede wszystkim zaś naświetlają to badania gustów współczesnych nastolatków, wskazujące, że w ostatnich latach młodzież słucha głównie hip-hopu i popu ${ }^{74}$. Prawdopodobnie więc naturalna przemiana pokoleń doprowadzi do tego, że w kolejnych dekadach w łonie studiów nad muzyką popularną rockologia - choć ciągle obecna i silna - będzie stopniowo wypierana przez hiphopologię.

Zapewne każdy ze śledzących losy polskiego wariantu rock music studies, a reprezentujący odmienną profesję muzyczną albo dyscyplinę akademicką, inaczej spogląda na dotychczasowe osiągnięcia i niedostatki polskiej rockologii. Istniejący dorobek z pewnością daje dużo satysfakcji, ale na pytanie, czego brakuje, co trzeba jeszcze zrobić, co jest najpilniejszą potrzebą tego nurtu namysłu nad kulturą, każdy z zainteresowanych odpowiedziałby odmiennie. Te pytania są jednak kluczowe dla dalszych perspektyw rozwoju rockologii w Polsce i nie wolno ich unikać.

Wydaje się, że jednym z najbardziej palących problemów rodzimego namysłu nad rockiem jest niewątpliwie jego niska internacjonalizacja - coś, co nazwałbym naukową wsobnością. Bolączkę stanowi zwłaszcza znikomy udział polskich badaczy rocka w międzynarodowych wydarzeniach typu konferencje, sympozja albo warsztaty, a także brak rodzimych autorów w zagranicznych publikacjach zbiorowych, zwłaszcza w anglojęzycznych monografiach bądź międzynarodowych encyklopediach, leksykonach czy słownikach. O nieobecności Polaków w gremiach redakcyjnych nie ma tu nawet co wspominać. Artykuły polskich badaczy są niemal zupełnie nieobecne w najważniejszych światowych pismach naukowych poświęconych muzyce popularnej, tj. działającym od 2014 roku „Rock Music Studies”,

74 Zob. T. Kukołowicz, Jakie sq gusta muzyczne polskich nastolatków? Mamy wyniki badań!, https://www.nck.pl/badania/aktualnosci/preferencje-muzycznenastolatkow [dostęp 20.01.2020]. Natomiast badania przeprowadzone jeszcze na przełomie 2013 i 2014 roku wskazywały, że rock jest ciągle najczęściej słuchaną muzyką w grupie wiekowej 15-30, a hip-hop zajmował, wespół z reggae, miejsce za rockiem i popem. Zob. A. Białkowski, M. Migut, Z. Socha, K.M. Wyrzykowska, Muzykowanie w Polsce. Badanie podstawowych form aktywności muzycznych Polaków, Warszawa 2014, s. 57. 
wychodzącym od 1981 roku w Wielkiej Brytanii „Popular Music” albo ukazującym się w USA już od 1976 roku periodyku „Popular Music \& Society”. Polaków brakuje też w najważniejszych instytucjach międzynarodowych zajmujących się muzyką rockową i muzyką popularną, i nie chodzi tu wcale o piastowanie jakichś istotnych funkcji, ale zwykłe członkostwo i uczestnictwo w wydarzeniach przez nie organizowanych. Przykładem niech będzie choćby The International Association for the Study of Popular Music (IASPM), założone w 1981 roku w Amsterdamie przez muzyków i badaczy kultury z różnych dyscyplin i różnych krajów. Obecnie jest to największa tego typu organizacja na świecie, skupiająca niemal tysiąc członków i mająca szereg oddziałów w poszczególnych krajach. IASPM organizuje co dwa lata biennale w różnych częściach świata - największe tego typu konferencje poświęcone muzyce popularnej, na których pojawia się nawet kilkuset uczestników, w tym również wielu artystów czy przedstawicieli branży muzycznej. Brak rodaków w tych przedsięwzięciach daje za granicą błędne wrażenie, że Polska jest pustynią rockologii i badań nad muzyką popularną oraz że w zasadzie w Polsce nie ma kompetentnych badaczy z tego zakresu, z którymi można by nawiązać współpracę. Udział Polaków w tych inicjatywach nie tylko spopularyzowałby na świecie polską rockologię i badania w jej ramach prowadzone, ale również polską muzykę i kulturę rockową.

Ostatnie lata dają jednak światło nadziei na przełamanie tego impasu. Pod koniec 2016 roku z inicjatywy Ewy Mazierskiej - polskiej badaczki pracującej w University of Central Lancashire - ukazała się w Wielkiej Brytanii książka Popular Music in Eastern Europe. Breaking the Cold War Paradigm z kilkoma rozdziałami o polskiej muzyce rockowej ${ }^{75}$. W 2017 roku członkowie IASPM redagujący serię Made in..., poświęconą muzyce popularnej w nieanglojęzycznych krajach, zwrócili się z prośbą do Patryka Gałuszki o podjęcie prac nad tomem Made in Poland, co zaowocowało wydaniem go pod koniec 2019 roku $^{76}$. Ponadto włoski badacz Leonardo Masi, pracownik Wydziału Nauk Humanistycznych UKSW, we współpracy z Janem Blümlem (Uniwersytet Palackiego w Ołomuńcu) i Markiem Jezińskim (Uniwersytet Mikołaja Kopernika w Toruniu) zorganizował w dniach 10-11 października

75 Popular Music in Eastern Europe. Breaking the Cold War Paradigm, ed. E. Mazierska, London 2016.

${ }^{76}$ Made in Poland. Studies in Popular Music, ed. P. Gałuszka, London 2019. 
2019 roku międzynarodową konferencję Popular Music Studies in Europe: History, Methodolgies, Perspectives, na którą zaprosił czołowych badaczy muzyki popularnej i rocka z Polski i krajów Europy Środkowej, a także obecnego przewodniczącego IASPM Ruperta Tilla oraz włoskich przedstawicieli tego stowarzyszenia. Jednym z głównych tematów tego sympozjum była dyskusja nad możliwością konsolidacji i instytucjonalizacji badań muzyki popularnej w ramach polskiego lub środkowoeuropejskiego oddziału IASPM. Wszystkie te wydarzenia dobrze rokują na przyszłość, dając nadzieję na dalszy rozwój polskiej rockologii, a zwłaszcza jej umiędzynarodowienie.

\section{Bibliografia}

Joachim Ernst Berendt, Od raga do rocka. Wszystko o jazzie, tłum. W. Panek, PWM, Kraków 1979.

Andrzej Białkowski, Mateusz Migut, Ziemowit Socha, Katarzyna M. Wyrzykowska, Muzykowanie w Polsce. Badanie podstawowych form aktywności muzycznych Polaków, Fundacja na rzecz rozwijania muzykalności Polaków „Muzyka jest dla wszystkich", Warszawa 2014.

Karolina Bittner, Partia z piosenka, piosenka z partia. PZPR wobec muzyki rozrywkowej, IPN, Warszawa 2017.

Wojciech Bonowicz, Wojciech Waglewski, Wagiel. Jeszcze wszystko będzie możliwe, SIW Znak, Kraków 2017.

Dariusz Brzostek, Nastuchiwanie hałasu. Audioantropologia między ekspresja a doświadczeniem, WN UMK, Toruń 2014.

Wojciech Burszta, Marcin Rychlewski, Odpowiedź na pytanie: po co nam rock?, [w:] A po co nam rock? Między dusza a ciałem, red. eidem, Wydawnictwo Książkowe „Twój Styl”, Warszawa 2003.

"Chodzac wich butach". Depeche Mode - muzyka, zjawisko, recepcja, red. M. Jurzysta, M. Pranke, P. Tański, Wydawnictwo ProLog, Torun 2017.

Czesław Niemen i jego płytowe dzieła, red. E. Chlebowska, P. Chlebowski, współudział $€$. Niewczas, Wydawnictwo KUL, Lublin 2014.

Czesław Niemen i jego plytowe dzieła, cz. 2, red. E. Chlebowska, P. Chlebowski, Wydawnictwo KUL, Lublin 2017.

Czesław Niemen i jego plytowe dzieła, cz. 3, red. E. Chlebowska, P. Chlebowski, Wydawnictwo KUL, Lublin 2020.

Marek Ćwikła, Jan Kawecki, Janusz Sadłowski, Wojciech Zając, Encyklopedia polskiej muzyki rockowej. Rock'n'roll 1959-1973, Rock-Serwis, Kraków 1995. 
Andrzej Dorobek, Rock - problemy, sylwetki, konteksty (szkice z estetyki i socjologii rocka), Instytut Wydawniczy „Świadectwo”, Bydgoszcz 2001.

Encyklopedia Muzyki Popularnej. Heavy rock, red. R. Gloger, OW Atena, Poznań 2000.

Etyka i estetyka słowa w piosence, red. M. Chrząstowska, K. Gajda, WN UAM, Poznań 2019.

Marian Filipiak, Od subkultury do kultury alternatywnej: wprowadzenie do subkultur młodzieżowych, Wydawnictwo UMCS, Lublin 1999.

Krzysztof Gajda, Szarpidruty i poeci. Piosenka wobec przemian społecznych i kulturowych ostatnich dekad, WN UAM, Poznań 2017.

Krzysztof Gajda, Krzysztof Grabowski, Gościu: Auto-Bio-Grabaż, InRock, Poznań 2010.

Tony Gale, Encyklopedia Muzyki Popularnej. Lata sześćdziesiąte, OW Atena-RockSerwis, Poznań 1995.

Marek Garztecki, Rock od Presleya do Santany, PWM, Kraków 1978.

Ryszard Gloger, Wojciech Skrzydlewski, Ilustrowany leksykon muzyki popularnej, Wydawnictwo Kurpisz, Poznań 2002.

Leszek Gnoiński, Jan Skaradziński, Encyklopedia Polskiego Rocka, In Rock, Poznań 1996.

Marian Golka, Od kontrkultury do popkultury, Wydawnictwo Fundacji Humaniora, Poznań 2002.

Mariusz Gradowski, Big beat. Style i gatunki polskiej muzyki młodzieżowej w latach 1957-1973, OW ASPRA, Warszawa 2018.

Juliusz Jerzy Herlinger, Andrzej Jakubowicz, Maria Jurkowska, Lucjan Kydryński, Antoni Marianowicz, Dariusz Michalski, Aleksander Jerzy Rowiński, Andrzej Stankiewicz, Adam Warecki, Cały ten „jazz”, Wiedza Powszechna, Warszawa 1990.

Beata Hoffmann, Rock a przemiany kulturowe końca XX wieku, WN Semper, Warszawa 2001.

Anna Idzikowska-Czubaj, Rock w PRL-u. O paradoksach współistnienia, Wydawnictwo Poznańskie, Poznań 2011.

Marek Jakubowski, Encyklopedia Muzyki Popularnej. Blues, OW Atena, Poznań 2008.

Marek Jakubowski, Mariusz Szalbierz, Encyklopedia Muzyki Popularnej. Blues w Polsce, OW Atena, Poznań 1997. 
Witold Jakubowski, Edukacja w świecie kultury popularnej, OW Impuls, Kraków 2011.

Marek Jeziński, Mitologie muzyki popularnej, WN UMK, Toruń 2014.

Marek Jeziński, Muzyka popularna i jej odbiorcy w poszukiwaniu autorytetu, WN UMK, Toruń 2017.

Marek Jeziński, Muzyka popularna jako wehikuł ideologiczny, WN UMK, Toruń 2011.

Marek Jędrzejewski, Młodzież a subkultury, Wydawnictwo Akademickie Żak, Warszawa 1999.

Jakub Kasperski, Muzyka popularna jako przedmiot badań muzykologii, praca doktorska napisana pod kierunkiem prof. dra hab. Ryszarda Daniela Golianka, UAM, Poznań 2012.

Jakub Kasperski, Tożsamość muzykologii w pespektywie badań nad muzyką popularna, [w:] Kultura popularna w społeczeństwie współczesnym. Teoria i rzeczywistość, red. J. Drozdowicz, M. Bernasiewicz, OW Impuls, Kraków 2010. Remigiusz Kasprzycki, Dekada buntu. Punk w Polsce i krajach sasiednich w latach 1977-1989, Libron, Kraków 2013.

Izolda Kiec, W szarej sukience? Autorki i wokalistki w poszukiwaniu tożsamości, WN Scholar, Warszawa 2013.

Kontrkultura: co nam z tamtych lat?, red. W.J. Burszta, M. Czubaj, M. Rychlewski, Wydawnictwo SWPS, Warszawa 2005.

Rafał Księżyk, Kazik Staszewski, Idę tam gdzie idę. Autobiografia, Kosmos Kosmos, Warszawa 2015.

Tomasz Kukołowicz, Jakie sa gusta muzyczne polskich nastolatków? Mamy wyniki badań!, 31.01.2019, NCK, https://www.nck.pl/badania/aktualnosci/ preferencje-muzyczne-nastolatkow.

Jacek Kuroń, Umarł Jerzy Wertenstein-Żuławski, „Gazeta Wyborcza”, 30.10.1996.

Lucjan Kydryński, Wierzę piosence, PWM, Kraków 1959.

Lucjan Kydryński, Znajomi z Estrady, PWM, Kraków 1966.

Lucjan Kydryński, Znajomi z płyt, PWM, Kraków 1960.

Colin Larkin, Encyklopedia muzyki popularnej. Lata osiemdziesiąte, OW Atena, Poznań 2004.

Krzysztof Lesiakowski, Paweł Perzyna, Tomasz Toborek, Jarocin w obiektywie bezpieki, IPN, Warszawa 2004.

Piotr Łuszczykiewicz, Piosenka w poezji pokolenia ery transformacji 1984-2009, WN UAM, Poznań 2009. 
Made in Poland. Studies in Popular Music, ed. P. Gałuszka, Routledge, London 2019. Joanna Maleszyńska, Apologia piosenki. Studia z historii gatunku, WN UAM, Poznań 2013.

Anna Malewska-Szałygin, Antropologia i polityka - zastosowanie czy uwikłanie, [w:] Antropologia stosowana, red. M. Ząbek, Warszawa 2013.

Zbyszko Melosik, Kultura popularna i tożsamość młodzieży. W niewoli władzy i wolności, OW Impuls, Kraków 2013.

Dariusz Michalski, Czesław Niemen. Czy go jeszcze pamiętasz?, Wydawnictwo MG, Warszawa 2009.

Dariusz Michalski, 2. Rock przez caty rok; 3. Komu piosenkę?; 4. Z piosenka dookoła świata; 5. Za kulisami przeboju, Wiedza Powszechna, Warszawa 1990.

Między przymusem a akceptacja. Meandry władzy w literaturze i kulturze popular-

nej, red. A. Gemra, K. Doiminas, Pracownia Literatury i Kultury Popularnej oraz Nowych Mediów, Wrocław 2014.

Katarzyna Nosowska, A ja żem jej powiedziała..., Wielka Litera, Warszawa 2018. Wojciech Ossowski, Krzysztof Sawala (uzupełnienia i redakcja merytoryczna), Encyklopedia Muzyki Popularnej. Folk, tłum. L. Kaczmarek, T. Szczegóła, J. Weckwerth, OW Atena, Poznań 1996.

Wacław Panek, Encyklopedia muzyki rozrywkowej, Świat Książki, Warszawa 2000. Wacław Panek, Jazz, beat, rozrywka, Wydawnictwa Centralnego Ośrodka Metodyki Upowszechniania Kultury COK, Warszawa 1973.

Wacław Panek, Mały słownik muzyki rozrywkowej, ZAKR, Warszawa 1986.

Wacław Panek, Mity muzycznej rozrywki. Z notatnika obserwatora, Instytut Wydawniczy CRZZ, Warszawa 1976.

Wacław Panek, Niemen (kształty mitu), Wydawnictwo Jazz nad Odrą, Wrocław Brzeg 1974.

Wacław Panek, Nowy słowniczek muzyczny. Klasyka, folk, jazz, pop, rock, instrumenty, teoria, Wydawnictwo Polskie w Wołominie, Wołomin 2014.

Wacław Panek, Lech Terpiłowski, Piosenka polska, Krajowa Agencja Wydawnicza, Warszawa 1978.

Sławomir Pękała, Bogna Świątkowska, Hieronim Wrona, Encyklopedia Muzyki Popularnej. Rap, dance \& techno, OW Atena, Poznań 1997.

Dionizy Piątkowski, Encyklopedia Muzyki Popularnej. Jazz, OW Atena, Poznań 2005.

Grzegorz Piotrowski, Ałła Pugaczowa - fenomen piosenkarstwa rosyjskiego, Wydawnictwo Adam Marszałek, Toruń 2003. 
Grzegorz Piotrowski, Muzyka popularna. Nasłuchy i namysty, PIW, Warszawa 2016. Przemysław Piotrowski, Subkultury młodzieżowe. Aspekty psychospołeczne, Wydawnictwo Akademickie Żak, Warszawa 2003.

Popular Music in Eastern Europe. Breaking the Cold War Paradigm, ed. E. Mazierska,

Palgrave Macmillan, London 2016

Roman Radoszewski, Czesław Niemen. Kiedy się dziwić przestanę... Monografia artystyczna, Iskry, Warszawa 2004.

Marcin Rychlewski, Rewolucja rocka. Semiotyczne wymiary elektrycznej ekstazy, Wydawnictwo Oficynka, Gdańsk 2011.

Magdalena Saryusz-Wolska, Pamięć zbiorowa i kulturowa. Współczesna perspektywa niemiecka, TAiWPN Universitas, Kraków 2009.

Wojciech Siwak, Estetyka rocka, WN Semper, Warszawa 1993.

Tadeusz Skliński, Niemen. Dyskografia, fakty, twórczość, Nemunas, Warszawa 2006. Spontaniczna kultura młodzieżowa: wybrane zjawiska, red. M. Pęczak, J. Wertenstein-Żuławski, Wiedza o Kulturze, Wrocław 1991.

Paweł Tański, Dyskursy, performanse tekstowe i narracje transmedialne polskich piosenek rockowych, „Tematy i Konteksty” 2018, nr 8 (13).

Paweł Tański, Nowe sytuacje polskiego rocka: teksty, głosy, interpretacje, Instytut Kultury Popularnej, Poznań 2016.

Mateusz Torzecki, Okładki płyt. Rzecz o wizualnym uniwersum albumów muzycznych, Instytut Kultury Popularnej, Poznań 2015.

Artur Mariusz Trudzik, Na początku był Jazz. 60 lat prasy muzycznej (jazz, rock) w Polsce, „Zeszyty Prasoznawcze” 2017, t. 60, nr 1 (229).

Artur Mariusz Trudzik, Polska prasa muzyczna $w$ dobie transformacji ustrojowej. „Tylko Rock” 1991-2002, WN Katedra, Gdańsk 2017.

W teatrze piosenki, red. I. Kiec, M. Tkaczyk, Poznańskie Studia Polonistyczne, Poznań 2005.

Aleksandra Walczak, Barbara Wiśniewska, Pamięć autobiograficzna, „Psychiatria i Psychologia Kliniczna" 2011, nr 11 (1).

Roman Waschko, Muzyka jazzowa i rozrywkowa. Przewodnik Iskier, Iskry, Warszawa 1970.

Wiesław Weiss, Rock Encyklopedia, cz. 1-2, Iskry, Warszawa 1991-1994.

Jerzy Wertenstein-Żuławski, Między nadzieja a rozpacza [rock, młodzież, społeczeństwo], Instytut Kultury, Warszawa 1993.

Jerzy Wertenstein-Żuławski, To tylko rock'n roll!, posłowie A. Jawłowska, ZAKR, Warszawa 1990. 
Adam Wolański, Słownik terminów muzyki rozrywkowej, WN PWN, Warszawa 2000.

Ryszard Wolański, Leksykon polskiej muzyki rozrywkowej. Pop, rock, jazz, folk, t. 1-3, MTJ, Warszawa 2003.

Halina Zgółkowa, „Miny na pokaz, czyny za grosz...”. O tekstach polskiego rocka, „Nurt” 1984, nr 1.

Halina Zgółkowa, Teksty rockowe: schematy myśli i języka, „Nurt” 1986, nr 5. Przemysław Zieliński, Scena rockowa $w$ PRL. Historia, organizacja, znaczenie, Wydawnictwo Trio, Warszawa 2005.

\section{Źródła internetowe}

http://fundacja-ikp.pl/wydawnictwo/page/2/.

http://panek.arway.waw.pl.

http://www.wydawnictwopolskie.pl/index.php/o-autorze-podrecznika-do-wok. http://wuwr.pl/lkp.

http://www.andersmusic.ch/01_musik/01_J_N_M/nachruf_berendt.html. https://fil.ug.edu.pl/strona/55340/biogram_dr_grzegorz_piotrowski. https://inrock.pl/o-nas/.

https://muzeumpiosenki.pl/piosenka-rocznik-kulturalny.html.

https://www.facebook.com/serwisprogrockorgpl/posts/1244652955556617/. https://www.swps.pl/nauka-i-badania/dzialalnosc-wydawnicza/czasopisma/ kultura-popularna.

\section{Akty prawne}

Uchwała nr XLII/825/17 Rady Miasta Opola z dnia 25 maja 2017 r. w sprawie nadania statutu Muzeum Polskiej Piosenki w Opolu, Dz.U. Województwa Opolskiego, 5.06.2017 r., https://muzeumpiosenki.pl/pliki/Statut_Muzeum_ Polskiej_Piosenki.pdf.

\section{The Development of 'Rockology' in Poland}

The article highlights the development of rock music studies in Poland, taking into account both (auto)biographical, journalistic, lowbrow and academic approaches. From a historical perspective, the subsequent stages of the formation of rockology are discussed here: from popularization works in the People's Republic of Poland, through free-market publications 
appearing since the 1990s, which filled the gaps from the previous era, satisfying the hunger for knowledge among rock fans, to the development of rock studies at universities, institutionalization of research, diversification and development of thematic specializations within individual disciplines. The article presents the development of the music press, book literature, publishing houses and institutions specializing in rock research. The issue of its future perspectives future is also raised: challenges, threats, but also the shortcomings of Polish 'rockology' in relation to the international context.

Keywords: rock music, Polish rock, rockology, rock music studies, popular music studies 